\title{
A Quantitative Approach to Evaluate the Financial Performance of Growth Oriented Bangladeshi Close - End Mutual Funds: An Empirical Study
}

\author{
By Washeka Anjom \\ Port City International University
}

Abstract- Mutual fund, an investment vehicle by retail investors, is playing a vital role in our capital market by transforming the sum of the invested funds of investors into investing in a diversified portfolio by the professional investment managers. Since 1980, the mutual funds have been emerging rapidly in the stock market of Bangladesh. This research work attempts to evaluate the financial performance of growth-oriented Bangladeshi Close-end mutual funds traded in Chittagong Stock Exchange (CSE). In order to fulfill the objectives of the paper, ten mutual funds out of thirty-six have chosen. The Prime data used is the Net Asset Value (NAV) of the selected mutual funds and the returns of the CS 30 as a benchmark index. This paper concentrates on the evaluation of mutual funds by employing various research methodologies such as Treynor's ratio, Sharpe ratio, and Jensen's alpha and Regression Analysis. Finally, an attempt has also undertaken to assess the statistical relationship between the performance CS 30 and the mutual funds.

Keywords: close-end mutual funds, chittagong stock exchange, benchmark return, CS 30, net asset value.

GJMBR-C Classification: JEL Code: G00

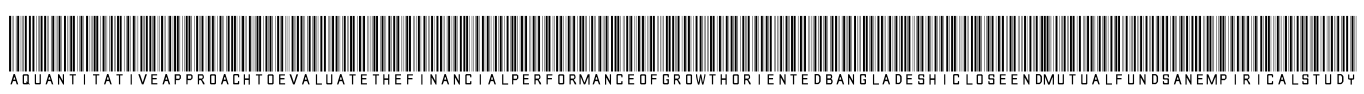

Strictly as per the compliance and regulations of:

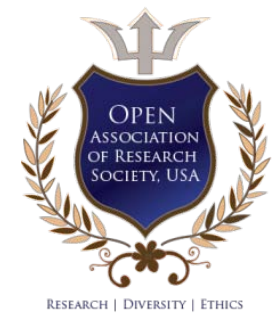

(c) 2020. Washeka Anjom. This is a research/review paper, distributed under the terms of the Creative Commons AttributionNoncommercial 3.0 Unported License http://creativecommons.org/licenses/by-nc/3.0/), permitting all non-commercial use, distribution, and reproduction in any medium, provided the original work is properly cited. 


\title{
A Quantitative Approach to Evaluate the Financial Performance of Growth Oriented Bangladeshi Close-End Mutual Funds: An Empirical Study
}

\author{
Washeka Anjom
}

Abstract-Mutual fund, an investment vehicle by retail investors, is playing a vital role in our capital market by transforming the sum of the invested funds of investors into investing in a diversified portfolio by the professional investment managers. Since 1980, the mutual funds have been emerging rapidly in the stock market of Bangladesh. This research work attempts to evaluate the financial performance of growth-oriented Bangladeshi Close-end mutual funds traded in Chittagong Stock Exchange (CSE). In order to fulfill the objectives of the paper, ten mutual funds out of thirty-six have chosen. The Prime data used is the Net Asset Value (NAV) of the selected mutual funds and the returns of the CS 30 as a benchmark index. This paper concentrates on the evaluation of mutual funds by employing various research methodologies such as Treynor's ratio, Sharpe ratio, and Jensen's alpha and Regression Analysis. Finally, an attempt has also undertaken to assess the statistical relationship between the performance CS 30 and the mutual funds. The results of the analysis show poor performance of the mutual funds in the CSE. Outcomes of the study have failed to comply with the objectives of the study. The implication of the study is that it will assist the investors in making rational investment decisions for the utilization of the funds in the correct mutual funds. Apart from the performances of the selected mutual funds, there may have many other factors motivating the investors to allocate their funds in mutual funds. Further research can conduct incorporating this issue.

Keywords: close-end mutual funds, chittagong stock exchange, benchmark return, CS 30, net asset value.

\section{InTRODUCTION}

A $\mathrm{n}$ investment decision is a crucial decision for an investor to generate a fair return from the lutilization of surplus funds. Making an investment decision requires to have a thorough consideration of many determinants, including the risk and return, liquidity, marketability and tax benefits, etc. Mutual fund paves the way for investing the investment in an asset group of preference such as equity or debt. Not only the large investors but also the small investors have been motivating to have exposure in the financial markets through a mutual fund.

A mutual fund is a financial intermediary that pools money by selling shares to the public and invest the proceeds in a diversified portfolio of securities. Each

Author: Port City International University. e-mail: adnin09@yahoo.com share sold represents a proportional interest in the securities managed by the investment company on behalf of its unit-holders. In another word, an investment company that is entitled to collect money from investors and invests the money in stocks, bonds, money-market securities, or a combination of other securities referred to as a mutual fund. A mutual fund is a cost-efficient investment vehicle chosen by investors to have financial excellence in terms of obtaining high returns. Investors sharing a common investment objective become the shareholder of the fund by purchasing shares or units of the mutual fund. Investors may differ in buying the shares of the mutual fund depending on the personal investment objectives too. The parties who are involved with the management of the mutual funds are Sponsors, Board of Trustees, Asset Management Company and Custodian.Net Asset Value (NAV) is the intrinsic value and market price of the particular scheme.NAV shows the appreciation or depreciation of the money invested in a specific plan.

Investors, or shareholders have been used interchangeably throughout the study. The role played by mutual funds has created economic motivation for the investors. By investing in mutual fund schemes, the investor can effectively achieve the benefits of diversification at a lower cost, even with a small amount of money. Investors are also able to reduce a variety of costs related to investment and management of portfolios as investors purchase the services of a presumably skilled financial advisor at less price than if the investor directly and individually negotiated with such an advisor. Most importantly, mutual funds provide liquidity for the investors as it can be bought or liquidated any day at the closing NAV. The number of assets in mutual funds have been growing significantly over time. Bangladesh has witnessed exponential growth in the mutual fund industry. The number of and assets in mutual funds have been growing notably over the years.

\section{Literature Review}

Diversified quantitative and qualitative research works have conducted to evaluate the performance of 
mutual funds by the distinguished researchers around the globe.

According to Biplob, M. N. K. (2017), the majority of the selected closed-end mutual funds in the Dhaka Stock Exchange can generate returns, which is greater than the benchmark market index (DSEX) in terms of risk and return based on the results of different risk- adjusted performance measures. This is inconsistent with the results of this research work as none of the mutual funds traded in the Chittagong Stock exchange can outperform the benchmark market index (CS 30). He also explored whether the mutual funds provide the benefits of diversification, market timing, and selectivity of securities to their investors. It is the finding of his study that $60 \%$ of the selected mutual funds are well diversified. Besides, He did not find any significant relationship between timing skill and return of funds. He also emphasized the development of the institutional environment for the gradual progress of the mutual fund industry in Bangladesh.

According to Oleksandra, Lemeshko \& Oldrich, R. (2015), mutual funds traded in emerging economies (evidence from BRIC, CEE, sea, and MENA regions) hardly generate returns above the market. The finding is that 4796 open-end active and non-active mutual funds from 27 emerging economies showed downward performance relative to their benchmarks. This underperforming trend continued to hold during the times of crisis, recession, the period of recovery and economic growth. Nonetheless, there are some topperforming funds in every region except MENA. These mutual funds continued to outperform irrespective of overall macroeconomic situation and local capital markets. This result is inconsistent with the findings of this research work.

According to Zaheeruddin, M. Sivakumar, P. Reddy, K. S. (2013), ICICl mutual fund of India generated high returns and low risk among the selected funds. Besides, it has revealed that Birla Sun Life mutual fund possessed high risk. They also ranked these mutual funds as per the performance ratios. Accordingly, $\mathrm{IClCl}$ has ranked in the top position. So, this finding will add insights into the decision- making criteria of the eligible investors to employ the funds in an appropriate investment vehicle.

According to Reddy, D. C. P. (2013), 14 schemes in India beat the benchmark return (Sensex). Besides, it has also revealed that 17 equity schemes have low total risk relative to benchmarks (Sensex, Nifty).

According to Prajapati, P. K. P \& Patel, P. M. (2012), the findings of the study reveal that all the mutual fund schemes in India have generated gain from 2007 to 2011. They have obtained it by using daily closing NAVs of mutual fund schemes of selected top five asset management companies from $1^{\text {st }}$ January 2007 to $31^{\text {st }}$
December 2011. Different risk -adjusted measures such as risk-return analysis, Sharape ratio, Treynor ratio, Jensen's measure, etc. have been used to conduct this research work. Besides, funds are less volatile than benchmark indexes.

According to Agarwal, S. \& Mirza, N. (2017), Sharpe and Treynor ratio of the selected mutual fund schemes in India indicated that $90 \%$ of the mutual funds have outperformed than the benchmark. Besides, the downside risk is comparatively higher, too supported by the analysis of value at risk for mutual funds.

According to Kiyamaz, $\mathrm{H}$ \& Simsek, K. D. (2017), emerging markets of mutual funds differ from the developed markets based on liquidity, size and regulation. They took an attempt to examine the performance of US-based emerging mutual funds total of 300 mutual funds have been chosen as a sample of diversified emerging markets funds (equity fund 222 and bond fund 78) from January 2000 to May 2017. The findings show that $5 \%$ of diversified equity funds provide significant alphas to the investors as well as $6 \%$ of emerging market bond funds offer significant positive alphas

According to Kiymaz, H. (2015), it has been revealed that investor has positive alphas with investing in Chinese mutual funds. This is inconsistent with the results of this research work. Besides, there are enormous variations in generating returns by the Chinese mutual funds. These funds do not make an excess returns for the investors consistently.

According to Qamruzzaman. (2014), abnormal returns have been generated by most of the mutual funds in Bangladesh compared to benchmark return. His finding supports the investigation of the performance evaluation of 32 mutual funds listed in DSE.

According to Jayadev. (1996), mutual funds have not performed better than their benchmark indicator, and fund managers are not sufficiently able to use their market timing and selectivity skills.

\section{ili. Objectives of the Study}

The prime aim of the paper is to evaluate the financial performance of the growth-oriented Bangladeshi close-end mutual funds traded in CS concerning the return of the benchmark index. Also, efforts have been there to identify the impact of the diversification and CS 30 on the return of the mutual funds.

\section{a) Hypotheses of the study}

H1. Returns of the benchmark index have influence on the return of the fund.

H2. Diversification and the return of CS 30 have an impact on the returns of the fund. 


\section{Research Methodology}

a) Sampling

Ten close-end mutual funds among 36 have been chosen for the study. The period of the research work is $31^{\text {st }}$ January 2013 to $31^{\text {st }}$ December 2017. This sampling has conducted based on the market capitalization of the mutual funds.

\section{b) Sources of the data collection}

The only the secondary source used to satisfy the objectives of this study. Quantitative data for conducting this research work have collected from the library of Chittagong Stock Exchange (CSE). Monthly NAV of the ten mutual funds has obtained. Besides, the dividend of the mutual funds has also considered to correct the NAV. 3- months Treasury bill rate is assumed as the benchmark for the risk -free rate.

c) Data Analysis techniques

Data Analysis techniques used for the study has shown below:

1. Sharpe's ratio

2. Treynor ratio
3. Jensen's Alpha

4. Regression analysis

V. Performance Evaluation of Mutual FundS: DISCUSSION OF THE EMPIRICAL FINDINGS

a) Jensen's Alpha

Michael Jensen, an American economist, has developed Jensen alpha, a portfolio performance measure to reflect the differentiation between the actual return of the portfolio and the expected return of the portfolio at a given level of systematic risk.

Portfolio managers use Jensen's Alpha, a popular risk-adjusted performance measure to measure how much excess returns the portfolio has earned over and above the market returns as proposed by the CAPM model. A portfolio with a positive alpha outperforms the market and vice-versa.

Table 6.1: Results of Jensen's Alpha

\begin{tabular}{|lc|}
\hline \multicolumn{2}{|c|}{ Name of the Close-End Mutual Funds Jensen's Alpha } \\
\hline First Bangladesh Fixed Income Fund & -0.04649 \\
Grameen Mutual Fund One: Scheme Two & -0.0502 \\
Lr Global Bangladesh Mutual Fund One & -0.04491 \\
Trust Bank First Mutual Fund & -0.0394 \\
First Janata Bank Mutual Fund & -0.05627 \\
Popular Life First Mutual Fund & -0.04619 \\
Php First Mutual Fund & -0.04223 \\
Vanguard Aml Rupali Bank Balanced Fund & -0.04761 \\
Green Delta Mutual Fund & -0.04157 \\
Ab Bank 1st Mutual Fund & -0.03743 \\
\hline
\end{tabular}

None of the ten mutual funds has been able to generate a higher return than the equilibrium return as evidenced by the negative alpha. Thus, it indicates that funds have underperformed the market reflecting the weak performance of the fund manager in fulfilling the investment objectives.

b) Treynor ratio

Treynor ratio, a composite measure of portfolio performance, was developed by the Treynor to measure the excess return per unit of beta (systematic risk). It is also known as a reward to volatility ratio. The benchmark is the excess returns of the market over the market representing a superior performance of the fund.

Table 6.2: Results of the Treynor ratio

\begin{tabular}{|c|c|}
\hline Name of the close-end mutual funds & Treynor ratio \\
\hline First Bangladesh Fixed Income Fund & -2.092867802 \\
\hline Grameen Mutual Fund One:Scheme Two & $5.618365765-0.04235$ \\
\hline Lr Global Bangladesh Mutual Fund One & -0.573476851 \\
\hline Trust Bank First Mutual Fund & -0.254628845 \\
\hline First Janata Bank Mutual Fund & 0.200459048 \\
\hline Popular Life First Mutual Fund & 1.767277375 \\
\hline Php First Mutual Fund & -0.503602701 \\
\hline Vanguard Aml Rupali Bank Balanced Fund & $6.48001234-0.04235$ \\
\hline Green Delta Mutual Fund & $-0.322985398-0.04235$ \\
\hline Ab Bank 1st Mutual Fund & $-0.21584895-0.04235$ \\
\hline
\end{tabular}


Four funds among the ten have experienced higher returns than the benchmark return in case of Treynor ratio. Also. VANGUARD AML RUPALI BANK BALANCED FUND has got the highest excess return over the risk -free return for taking per unit of systematic risk followed by Grameen Mutual Fund one: Scheme Two, First Janata Bank Mutual Fund and Popular Life First Mutual Fund. c) Sharpe ratio

William Sharpe, an American economist, developed Sharpe ratio, a risk-adjusted measure of performance, to evaluate the performance of a portfolio and its manager. It is also known as a reward to variability ratio as it measures the risk premium return per unit of total risk.

Table 6.3: Results of the Sharpe ratio

\begin{tabular}{|lc|}
\hline Name of the close-end mutual funds & Sharpe ratio \\
\hline First Bangladesh Fixed Income Fund & -0.534675511 \\
Grameen Mutual Fund One:Scheme Two & -0.963910856 \\
Lr Global Bangladesh Mutual Fund One & -0.859165039 \\
Trust Bank First Mutual Fund & -0.87010737 \\
First Janata Bank Mutual Fund & -0.681775774 \\
Popular Life First Mutual Fund & -0.822461929 \\
Php First Mutual Fund & -0.71047734 \\
Vanguard Aml Rupali Bank Balanced Fund & -1.138472964 \\
Green Delta Mutual Fund & -1.025123113 \\
Ab Bank 1st Mutual Fund & -0.789085754 \\
\hline
\end{tabular}

All the mutual funds have a negative Sharpe ratio than that of the benchmark market index. Overall, mutual funds in Bangladesh are not in a good position than the benchmark index. The return of mutual funds failed to beat the return of CS 30 . So, the fund manager needs to change the structure and investment strategy of the portfolio.

d) Diversification

A coefficient of determination, a statistical tool, can be used to measure the diversification of the

\section{Table 6.4: Results of the Coefficient of determination}

\begin{tabular}{|lc|}
\hline Name of the close- end mutual funds & Coefficient of determination \\
\hline First Bangladesh Fixed Income Fund & 0.000111447 \\
Grameen Mutual Fund One: Scheme Two & $5.02601 \mathrm{e}-05$ \\
Lr Global Bangladesh Mutual Fund One & 0.00231425 \\
Trust Bank First Mutual Fund & $2.42901 \mathrm{e}-06$ \\
First Janata Bank Mutual Fund & 0.013607869 \\
Popular Life First Mutual Fund & 0.031548739 \\
Php First Mutual Fund & 0.003294697 \\
Vanguard Aml Rupali Bank Balanced Fund & 0.006994435 \\
Green Delta Mutual Fund & 0.003924868 \\
Ab Bank 1st Mutual Fund & .163840585 \\
\hline
\end{tabular}

The higher value of the coefficient of determination indicates that funds are well diversified. GRAMEEN MUTUAL FUND ONE: SCHEME TWO has experienced the highest coefficient of determination (5.02601E-05), followed by the TRUST BANK FIRST MUTUAL FUND with the coefficient of determination of 2.42901E-06. The remaining eight have a lower coefficients of determination, indicating that they are not well-diversified portfolios and have some level of diversifiable risk. It has also identified that FIRST BANGLADESH FIXED INCOME FUND has obtained the portfolio. It is known to all that the unsystematic risk can remove with good diversification of portfolio. It is determined by regressing the portfolio's additional return against the additional market return. A high value of the coefficient of determination is the indicator of greater diversification of fund and vice-versa. lowest coefficient of determination among the ten mutual funds.

\section{e) Regression analysis}

The Regression analysis has done to find whether there is any statistical relationship between the return of CS 30 (benchmark index) and the return of each mutual fund. For this, a value of significance has derived through the regression analysis by regressing the return of each mutual fund against the return of CS 30 (Benchmark index).value of significance $F$ less than 
the .05 indicates only that there is an influence of the return of CS 30 on the return of each mutual fund.

Table 6.5: Results of the Regression analysis

\begin{tabular}{|cc|}
\hline Name of the close-end mutual funds & Significance F \\
\hline First Bangladesh Fixed Income Fund & 0.936193 \\
Grameen Mutual Fund One:Scheme Two & 0.957126 \\
Lr Global Bangladesh Mutual Fund One & 0.715107 \\
Trust Bank First Mutual Fund & 0.990571 \\
First Janata Bank Mutual Fund & 0.374747 \\
Popular Life First Mutual Fund & 0.174553 \\
Php First Mutual Fund & 0.663112 \\
Vanguard Aml Rupali Bank Balanced Fund & 0.525231 \\
Green Delta Mutual Fund & 0.634406 \\
Ab Bank 1st Mutual Fund & 0.01337 \\
\hline
\end{tabular}

Values of significance an $F$ in the regression analysis show that none of the mutual funds have $F$ value of less than .05. It indicates that there is no statistical or significant relationship between the return of the CS 30 and the return of the mutual funds. So, the return of CS 30 does not influence on the return of the mutual funds.

\section{Test of the Hypotheses}

\begin{tabular}{|c|c|}
\hline Hypotheses & Remarks with discussion \\
\hline $\mathrm{H} 1$ & $\begin{array}{l}\text { Inconsistent with } \mathrm{H} 1 \text { as Returns of the benchmark index have no influence on the return of the } \\
\text { fund }\end{array}$ \\
\hline $\mathrm{H} 2$ & $\begin{array}{l}\text { Inconsistent with } \mathrm{H} 2 \text { as Diversification and return of CS } 30 \text { have no impact on the returns of the } \\
\text { fund. }\end{array}$ \\
\hline
\end{tabular}

\section{Vil. Limitations of The Study}

a. This study concentrates on only some selected closed-end mutual funds. This sample may not represent the actual performance of the mutual fund industry in Bangladesh.

b. The irrationality of the investors is far away from this study.

c. There may have factors beyond the NAV which have not considered in this study.

d. This study is based on only secondary data.

\section{Vili. Conclusion}

Recently, many of the mutual funds are trading below their NAV, hurting the retail investors. Due to the poor performance of some of the mutual funds, investors are losing confidence in it, walking away, investing further. A low dividend makes the investors reluctant towards mutual funds. Lack of integrity and inefficiency in managing the funds by the issue managers have identified by the stock analyst as another reason for the poor performance of the mutual funds. Besides, it expects that non-performing mutual funds be liquidated from the market and return the money to the investors. Fund managers should comply the ethical practices, professionalism, and ruleregulation to build trust and confidence among the investors. With some risk -adjusted performance measurement, this paper found that hardly funds have generated superior returns than benchmark return.
These findings show that the mutual funds traded in CSE fail to perform better than the CS 30. It strongly suggests that fund managers should develop investment strategy wisely within the framework of regulatory compliance so that more investors are prone to investing in mutual fund making a vibrant environment of investment for all. The findings of the study would assist the investors in making the correct investment decision supported by the historical data analysis of the mutual fund.

\section{References Références Referencias}

1. Reddy, D. C. P. (2013). The Performance of the sample mutual fund schemes. IQSR Journal of Business and Management, 18-24.

2. Kiymaz, H. (2015). A performance evaluation of Chinese mutual funds. International journal of emerging markets, 10: 4,820-836.DOl10.1108/IJo EM-09-2014-0136

3. Kiyamaz, H \& Simsek. (2017). The Performance of US-based emerging market mutual funds. Journal of Capital Markets studies, 1:1, 58-73. DOI. 10.1108/JCMS-10-2017-003

4. Jayadev. (1996). an analysis of monthly returns. Finance India X, 73-84.

5. Oleksandra, Lemeshko \& Oldrich. (2015). Performance evaluation of equity mutual funds in countries with emerging economies: Evidence from BRIC, CEE, sea and MENA regions. Procedia Economics and Finance 30, 476-486. 
6. Biplob, M. N. K. (2017). Performance Evaluation of Bangladesh Mutual Fund. International Journal of Economics \& Management Sciences, 6:3.

7. Zaheeruddin, M. Sivakumar, P. Reddy, K. S. (2013). Performance evaluation of mutual funds in India with special reference to selected financial intermediaries. IOSR Journal of Business and Management 7:2, 34-40.

8. Prajapati, P. K. P \& Patel, P. M. (2012). Comparative study on performance evaluation of mutual fund schemes of Indian companies. Journal of Arts, Science \& Commerce. 3:3,47-59.
9. Qamruzzaman. (2014). Comparative Study on performance evaluation of mutual fund schemes in Bangladesh: An analysis of monthly returns. Journal of Business Studies Quarterly 5, 190-209. DOI: 10.4172/2162-6359.1000428

10. Agarwal, S. \& Mirza, N. (2017). A study on the riskadjusted performance of mutual funds industry in India. Review of Innovation and Competitiveness, 3:1, 75-94.

\section{APPENDIX-1}

\begin{tabular}{|c|c|}
\hline $\begin{array}{l}\text { Name of the close-end mutual funds } \\
\text { Capitalization (Amount in BDT) }\end{array}$ & Market \\
\hline 1.First Bangladesh Fixed Income Fund & $4,107,421,287.20$ \\
\hline 2.Grameen Mutual Fund One: Scheme Two & $2,827,167,465.50$ \\
\hline 3.Lr Global Bangladesh Mutual Fund One & $2,457,534,622.80$ \\
\hline 4.Trust Bank First Mutual Fund & $1,820,563,872.00$ \\
\hline 5.First Janata Bank Mutual Fund & $1,762,965,318.40$ \\
\hline 6.Popular Life First Mutual Fund & $1,710,890,622.00$ \\
\hline 7.Php First Mutual Fund & $1,686,834,210.60$ \\
\hline 8.Vanguard Aml Rupali Bank Balanced Fund & $1,603,324,500.00$ \\
\hline 9.Green Delta Mutual Fund & $1,395,000,000.00$ \\
\hline 10.Ab Bank 1st Mutual Fund & $1,389,712,931.40$ \\
\hline 11.Ebl First Mutual Fund & $1,367,388,671.70$ \\
\hline 12.Southeast Bank 1st Mutual Fund & $1,367,044,910.00$ \\
\hline 13.Ebl Nrb Mutual Fund & $1,353,390,464.00$ \\
\hline 14.Dbh First Mutual Fund & $1,128,000,000.00$ \\
\hline 15.Ific Bank 1st Mutual Fund & $1,064,258,203.80$ \\
\hline 16.Icb Amcl Second Nrb Mutual Fund & $1,020,000,000.00$ \\
\hline 17.Vanguard Aml Bd Finance Mutual Fund One & $959,744,000.00$ \\
\hline 18.Exim Bank 1st Mutual Fund & $904,004,831.60$ \\
\hline 19.Nccbl Mutual Fund-1 & $878,877,548.10$ \\
\hline 20.Icb Amcl Sonali Bank Limited 1st Mutual Fund & $860,000,000.00$ \\
\hline 21.Mbl 1st Mutual Fund & $860,000,000.00$ \\
\hline 22.Aibl 1st Islamic Mutual Fund & $810,000,000.00$ \\
\hline 23.Icb Amcl First Agrani Bank Mutual Fund & $775,392,900.00$ \\
\hline 24.Ifil Islamic Mutual Fund-1 & $760,000,000.00$ \\
\hline 25.Nli First Mutual Fund & $755,007,000.00$ \\
\hline 26.Seml Ibbl Shariah Fund & $720,000,000.00$ \\
\hline 27.Prime Bank 1st Icb Amcl Mutual Fund & $710,000,000.00$ \\
\hline 28.1st Scheme Of Reliance Ins. Mf & $695,750,000.00$ \\
\hline 29.Asian Tiger Sandhani Life Growth Fund & $667,289,340.00$ \\
\hline 30.Icb Amcl Third Nrb Mutual Fund & $630,000,000.00$ \\
\hline 31.Icb Employees Provident Mutual Fund One & $525,000,000.00$ \\
\hline 32.Capm Bdbl Mutual Fund 01 & $441,152,800.00$ \\
\hline 33.Phoenix Finance 1st Mutual Fund & $420,000,000.00$ \\
\hline 34.Icb Amcl Second Mutual Fund & $405,000,000.00$ \\
\hline 35.Seml Lecture Equity Management Fund & $370,000,000.00$ \\
\hline 36.Prime Finance First Mutual Fund & $286,000,000.00$ \\
\hline
\end{tabular}

\section{APPENDIX-2}

Results of the Regression analysis between the returns of FIRST BANGLADESH FIXED INCOME FUND and the returns of CS 30 SUMMARY OUTPUT 
Regression Statistics

$\begin{array}{ll}\text { Multiple R } & 0.010556865 \\ \text { R Square } & 0.000111447 \\ \text { Adjusted R Square } & -0.01712801 \\ \text { Standard Error } & 0.090256715 \\ \text { Observations } & 60\end{array}$

\begin{tabular}{|c|c|c|c|c|c|c|c|c|}
\hline \multicolumn{9}{|l|}{ ANOVA } \\
\hline & $d f$ & SS & MS & F & $\begin{array}{c}\text { Significance } \\
\text { F }\end{array}$ & & & \\
\hline Regression & 1 & $5.27 \mathrm{E}-05$ & $5.27 \mathrm{E}-05$ & 0.006465 & 0.936193 & & & \\
\hline Residual & 58 & 0.472484 & 0.008146 & & & & & \\
\hline \multirow[t]{3}{*}{ Total } & 59 & 0.472537 & & & & & & \\
\hline & & & & & & & & \\
\hline & Coefficients & $\begin{array}{c}\text { Standard } \\
\text { Error }\end{array}$ & t Stat & P-value & Lower 95\% & $\begin{array}{l}\text { Upper } \\
95 \%\end{array}$ & $\begin{array}{l}\text { Lower } \\
95.0 \%\end{array}$ & $\begin{array}{l}\text { Upper } \\
95.0 \%\end{array}$ \\
\hline Intercept & -0.04645493 & 0.016996 & -2.73328 & 0.0083 & -0.08048 & -0.01243 & -0.08048 & -0.01243 \\
\hline $\begin{array}{c}\text { X Variable } \\
1\end{array}$ & 0.023449633 & 0.291651 & 0.080403 & 0.936193 & -0.56035 & 0.607252 & -0.56035 & 0.607252 \\
\hline
\end{tabular}

Results of the Regression Analysis between the returns of GRAMEEN MUTUAL FUND ONE:SCHEME TWO and the returns of CS 30

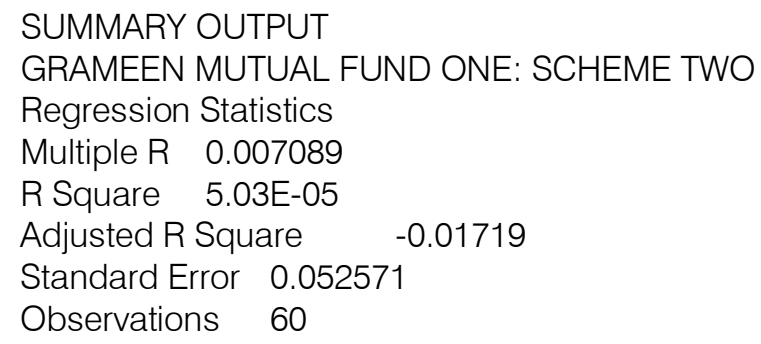

\begin{tabular}{|c|c|c|c|c|c|c|c|c|}
\hline ANOVA & & & & & & & \\
\hline & $\mathrm{df}$ & $\mathrm{SS}$ & $\mathrm{MS}$ & $\mathrm{F}$ & $\begin{array}{c}\text { Significance } \\
\mathrm{F}\end{array}$ & & & \\
\hline Regression & 1 & $8.06 \mathrm{E}-06$ & $8.06 \mathrm{E}-06$ & 0.002915 & 0.957126 & & & \\
\hline Residual & 58 & 0.160294 & 0.002764 & & & & & \\
\hline Total & 59 & 0.160302 & & & & & & \\
\hline & & & & & & & & \\
\hline & Coefficients & $\begin{array}{c}\text { Standard } \\
\text { Error }\end{array}$ & $\mathrm{t}$ Stat & P-value & Lower 95\% & Upper 95\% & $\begin{array}{c}\text { Lower } \\
95.0 \%\end{array}$ & $\begin{array}{c}\text { Upper } \\
95.0 \%\end{array}$ \\
\hline Intercept & -0.05021 & 0.0099 & -5.0722 & $4.32 \mathrm{E}-06$ & -0.07003 & -0.0304 & -0.07003 & -0.0304 \\
\hline $\begin{array}{c}\text { X Variable } \\
1\end{array}$ & -0.00917 & 0.169875 & -0.05399 & 0.957126 & -0.34921 & 0.330869 & -0.34921 & 0.330869 \\
\hline
\end{tabular}

Results of the Regression Analysis between the returns of LR GLOBAL BANGLADESH MUTUAL FUND ONE and returns of CS 30

\section{SUMMARY OUTPUT}

Regression Statistics

Multiple R 0.048107

R Square 0.002314

Adjusted R Square $\quad-0.01489$

Standard Error 0.057339

Observations 60

\begin{tabular}{|c|c|c|c|c|c|l|l|}
\hline ANOVA & & & & & & & \\
\hline & df & SS & MS & F & $\begin{array}{c}\text { Significance } \\
\text { F }\end{array}$ & & \\
\hline Regression & 1 & 0.000442 & 0.000442 & 0.134538 & 0.715107 & & \\
\hline
\end{tabular}




\begin{tabular}{|c|c|c|c|c|c|c|c|c|}
\hline Residual & 58 & 0.190693 & 0.003288 & & & & & \\
\hline Total & 59 & 0.191135 & & & & & & \\
\hline & Coefficients & $\begin{array}{c}\text { Standard } \\
\text { Error }\end{array}$ & t Stat & P-value & Lower 95\% & Upper 95\% & $\begin{array}{c}\text { Lower } \\
95.0 \%\end{array}$ & $\begin{array}{c}\text { Upper } \\
95.0 \%\end{array}$ \\
\hline & -0.05111 & 0.010282 & -4.97099 & $6.24 \mathrm{E}-06$ & -0.07169 & -0.03053 & -0.07169 & -0.03053 \\
\hline $\begin{array}{c}\text { Intercept } \\
\text { X Variable } \\
1\end{array}$ & -0.05253 & 0.143213 & -0.36679 & 0.715107 & -0.3392 & 0.234143 & -0.3392 & 0.234143 \\
\hline & & & & & & & & \\
\hline
\end{tabular}

Results of the Regression Analysis between the returns of the TRUST BANK FIRST MUTUAL FUND and the returns of CS 30

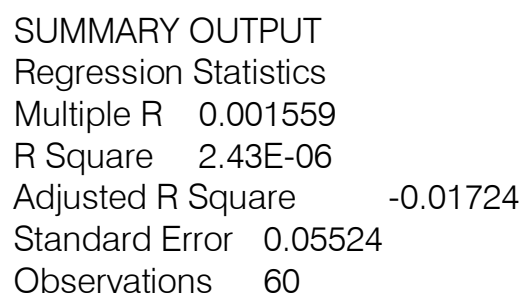

\begin{tabular}{|l|l|l|l|l|l|l|l|l|}
\hline ANOVA & & & & & & & \\
\hline & \multicolumn{1}{|c|}{$\mathrm{df}$} & $\mathrm{SS}$ & $\mathrm{MS}$ & $\mathrm{F}$ & $\begin{array}{l}\text { Significance } \\
\text { F }\end{array}$ & & & \\
\hline Regression & 1 & $4.3 \mathrm{E}-07$ & $4.3 \mathrm{E}-07$ & 0.000141 & 0.990571 & & & \\
\hline Residual & 58 & 0.176983 & 0.003051 & & & & & \\
\hline Total & 59 & 0.176983 & & & & & & \\
\hline & & & & & & & & \\
\hline & Coefficients & $\begin{array}{c}\text { Standard } \\
\text { Error }\end{array}$ & t Stat & P-value & Lower 95\% & Upper 95\% & $\begin{array}{l}\text { Lower } \\
95.0 \%\end{array}$ & $\begin{array}{l}\text { Upper } \\
95.0 \%\end{array}$ \\
\hline $\begin{array}{l}\text { Intercept } \\
1\end{array}$ & -0.04718 & 0.009905 & -4.7628 & $1.32 \mathrm{E}-05$ & -0.067 & -0.02735 & -0.067 & -0.02735 \\
\hline
\end{tabular}

Results of the Regression Analysis between the returns of the FIRST JANATA BANK MUTUAL FUND and the returns of CS 30

\section{SUMMARY OUTPUT}

Regression Statistics

Multiple R 0.116652772

R Square 0.013607869

Adjusted R Square $\quad-0.003398892$

Standard Error 0.068828834

Observations 60

\begin{tabular}{|c|c|c|c|c|c|c|c|c|}
\hline ANOVA & & & & & & & \\
\hline & $\mathrm{df}$ & $\mathrm{SS}$ & $\mathrm{MS}$ & $\mathrm{F}$ & $\begin{array}{c}\text { Significance } \\
\mathrm{F}\end{array}$ & & & \\
\hline Regression & 1 & 0.003791 & 0.003791 & 0.800145 & 0.374747 & & & \\
\hline Residual & 58 & 0.27477 & 0.004737 & & & & & \\
\hline Total & 59 & 0.27856 & & & & & & \\
\hline & Coefficients & $\begin{array}{c}\text { Standard } \\
\text { Error }\end{array}$ & $\mathrm{t}$ Stat & P-value & Lower 95\% & Upper 95\% & $\begin{array}{c}\text { Lower } \\
95.0 \%\end{array}$ & $\begin{array}{c}\text { Upper } \\
95.0 \%\end{array}$ \\
\hline Intercept & -0.03879343 & 0.012342 & -3.14328 & 0.002632 & -0.0635 & -0.01409 & -0.0635 & -0.01409 \\
\hline $\begin{array}{c}\text { X Variable } \\
1\end{array}$ & 0.153774644 & 0.17191 & 0.894508 & 0.374747 & -0.19034 & 0.497889 & -0.19034 & 0.497889 \\
\hline
\end{tabular}


Results of the Regression Analysis between the returns of the POPULAR LIFE FIRST MUTUAL FUND and the returns of CS 30

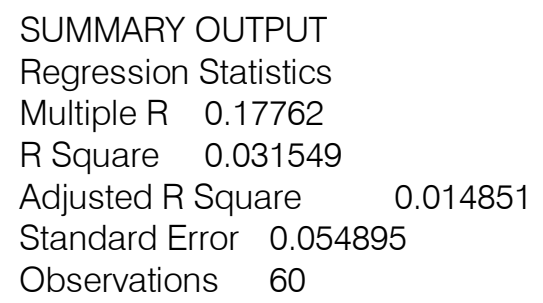

\begin{tabular}{|c|c|c|c|c|c|c|c|c|}
\hline ANOVA & & & & & & \\
\hline & $\mathrm{df}$ & SS & MS & F & $\begin{array}{c}\text { Significance } \\
\text { F }\end{array}$ & & \\
\hline Regression & 1 & 0.005694 & 0.005694 & 1.889436 & 0.174553 & & \\
\hline Residual & 58 & 0.174778 & 0.003013 & & & & & \\
\hline Total & 59 & 0.180472 & & & & & & \\
\hline & & & & & & & \\
\hline & Coefficients & $\begin{array}{c}\text { Standard } \\
\text { Error }\end{array}$ & t Stat & P-value & Lower 95\% & Upper 95\% & $\begin{array}{c}\text { Lower } \\
95.0 \%\end{array}$ & $\begin{array}{l}\text { Upper } \\
95.0 \%\end{array}$ \\
\hline Intercept & -0.0545 & 0.009843 & -5.53676 & $7.8 E-07$ & -0.0742 & -0.0348 & -0.0742 & -0.0348 \\
\hline $\begin{array}{c}\text { X Variable } \\
1\end{array}$ & -0.18846 & 0.137107 & -1.37457 & 0.174553 & -0.46291 & 0.085987 & -0.46291 & 0.085987 \\
\hline
\end{tabular}

Results of the Regression Analysis between the returns of the PHP FIRST MUTUAL FUND and the returns of CS 30

\begin{tabular}{|c|c|c|c|c|c|c|c|c|}
\hline SUMMARY OUTPU & & & & & & & & \\
\hline Regression Statistics & & & & & & & & \\
\hline Multiple R & 0.057399 & & & & & & & \\
\hline R Square & 0.003295 & & & & & & & \\
\hline Adjusted R Square & -0.01389 & & & & & & & \\
\hline Standard Error & 0.0659 & & & & & & & \\
\hline Observations & 60 & & & & & & & \\
\hline ANOVA & & & & & & & & \\
\hline & $d f$ & SS & MS & $F$ & $\begin{array}{c}\text { Significance } \\
F\end{array}$ & & & \\
\hline Regression & 1 & 0.000833 & 0.000833 & 0.191724 & 0.663112 & & & \\
\hline Residual & 58 & 0.251883 & 0.004343 & & & & & \\
\hline Total & 59 & 0.252715 & & & & & & \\
\hline & Coefficients & $\begin{array}{c}\text { Standard } \\
\text { Error }\end{array}$ & t Stat & $P$-value & Lower 95\% & $\begin{array}{l}\text { Upper } \\
95 \% \\
\end{array}$ & $\begin{array}{l}\text { Lower } \\
95.0 \% \\
\end{array}$ & $\begin{array}{l}\text { Upper } \\
95.0 \% \\
\end{array}$ \\
\hline Intercept & -0.04252 & 0.011817 & -3.59833 & 0.000664 & -0.06617 & -0.01887 & -0.06617 & -0.01887 \\
\hline X Variable 1 & 0.07207 & 0.164594 & 0.437863 & 0.663112 & -0.2574 & 0.401541 & -0.2574 & 0.401541 \\
\hline
\end{tabular}


Results of the Regression analysis between the returns of the VANGUARD AML RUPALI BANK BALANCED FUND and the returns of CS 30

SUMMARY OUTPUT

\begin{tabular}{|c|c|c|c|c|c|c|c|c|}
\hline \multicolumn{9}{|c|}{ Regression Statistics } \\
\hline Multiple R & $\begin{array}{c}0.08363274 \\
1 \\
\end{array}$ & & & & & & & \\
\hline R Square & $\begin{array}{c}0.00699443 \\
5\end{array}$ & & & & & & & \\
\hline $\begin{array}{l}\text { Adjusted R } \\
\text { Square }\end{array}$ & -0.01012635 & & & & & & & \\
\hline $\begin{array}{c}\text { Standard } \\
\text { Error }\end{array}$ & $\begin{array}{c}0.04211267 \\
6\end{array}$ & & & & & & & \\
\hline Observations & 60 & & & & & & & \\
\hline \multicolumn{9}{|l|}{ ANOVA } \\
\hline & $d f$ & SS & MS & $F$ & $\begin{array}{c}\text { Significanc } \\
\text { e F }\end{array}$ & & & \\
\hline Regression & 1 & 0.000725 & $\begin{array}{c}0.00072 \\
5\end{array}$ & $\begin{array}{c}0.40853 \\
5\end{array}$ & 0.525231 & & & \\
\hline Residual & 58 & 0.102862 & $\begin{array}{c}0.00177 \\
3 \\
\end{array}$ & & & & & \\
\hline \multirow[t]{2}{*}{ Total } & 59 & 0.103586 & & & & & & \\
\hline & Coefficients & $\begin{array}{l}\text { Standard } \\
\text { Error }\end{array}$ & t Stat & $P$-value & Lower 95\% & $\begin{array}{l}\text { Upper } \\
95 \%\end{array}$ & $\begin{array}{l}\text { Lower } \\
95.0 \%\end{array}$ & $\begin{array}{l}\text { Upper } \\
95.0 \%\end{array}$ \\
\hline Intercept & $\begin{array}{c}- \\
0.04395544 \\
2\end{array}$ & 0.007551 & -5.82097 & 2.68E-07 & -0.05907 & -0.02884 & -0.05907 & -0.02884 \\
\hline X Variable 1 & $\begin{array}{c}0.06722911 \\
3\end{array}$ & 0.105182 & $\begin{array}{c}0.63916 \\
7\end{array}$ & $\begin{array}{c}0.52523 \\
1\end{array}$ & -0.14332 & $\begin{array}{c}0.27777 \\
4\end{array}$ & -0.14332 & 0.277774 \\
\hline
\end{tabular}

Results of the Regression Analysis between the returns of the GREEN DELTA MUTUAL FUND and the returns of CS 30

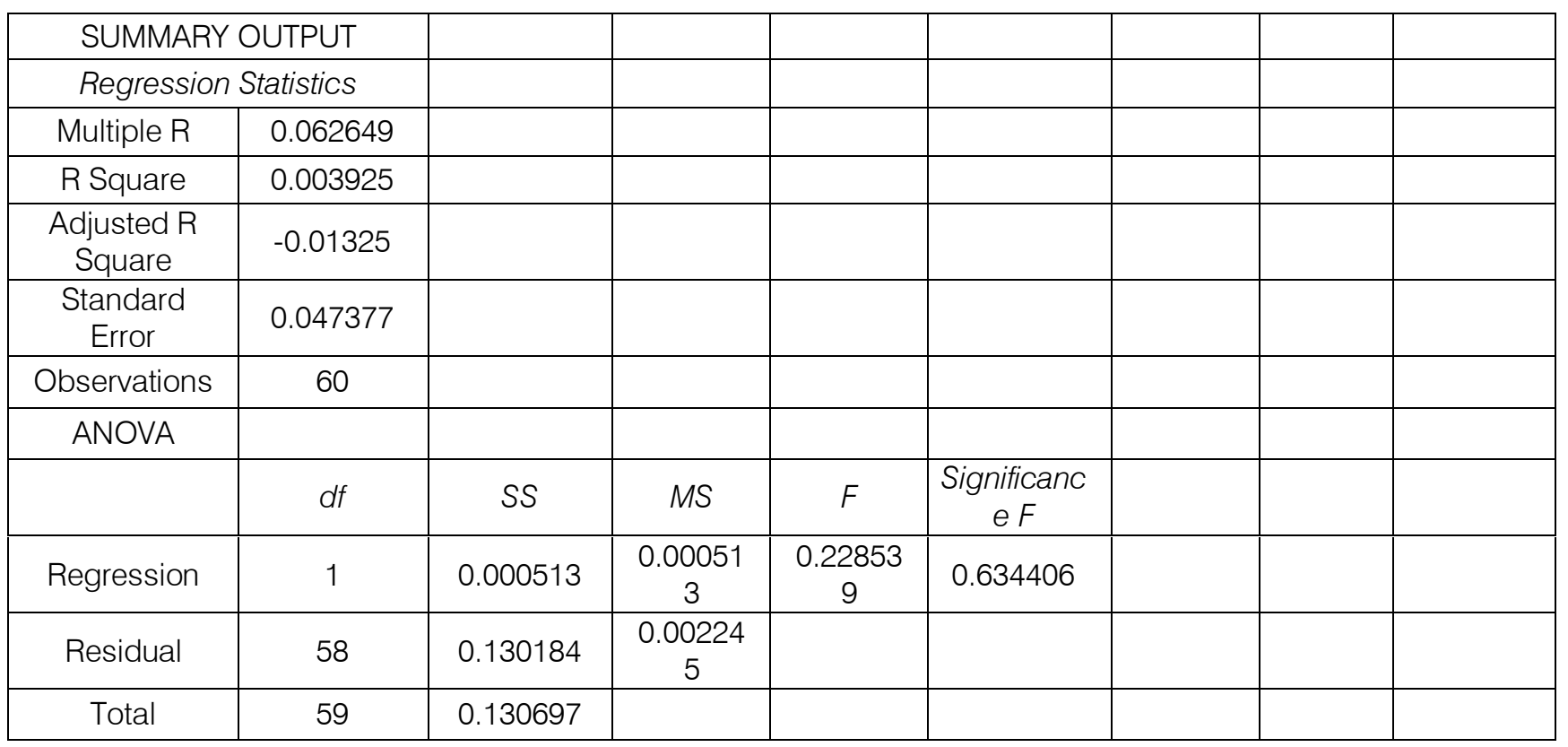




\begin{tabular}{|c|c|c|c|c|c|c|c|c|}
\hline & Coefficients & $\begin{array}{c}\text { Standard } \\
\text { Error }\end{array}$ & $t$ Stat & P-value & Lower 95\% & $\begin{array}{c}\text { Upper } \\
95 \%\end{array}$ & $\begin{array}{c}\text { Lower } \\
95.0 \%\end{array}$ & $\begin{array}{c}\text { Upper } \\
95.0 \%\end{array}$ \\
\hline Intercept & -0.05066 & 0.008495 & -5.96384 & $1.56 \mathrm{E}-07$ & -0.06767 & -0.03366 & -0.06767 & -0.03366 \\
\hline X Variable 1 & -0.05657 & 0.11833 & -0.47806 & $\begin{array}{c}0.63440 \\
6\end{array}$ & -0.29343 & $\begin{array}{c}0.18029 \\
5\end{array}$ & -0.29343 & 0.180295 \\
\hline
\end{tabular}

Results of the Regression Analysis between the returns of the AB BANK 1ST MUTUAL FUND and the returns of CS 30

SUMMARY OUTPUT

\begin{tabular}{|c|c|c|c|c|c|c|c|c|}
\hline \multicolumn{9}{|c|}{ Regression Statistics } \\
\hline Multiple R & 0.404772263 & & & & & & & \\
\hline R Square & 0.163840585 & & & & & & & \\
\hline $\begin{array}{c}\text { Adjusted R } \\
\text { Square } \\
\end{array}$ & 0.149424043 & & & & & & & \\
\hline $\begin{array}{c}\text { Standard } \\
\text { Error }\end{array}$ & 0.054881147 & & & & & & & \\
\hline Observations & 60 & & & & & & & \\
\hline \multicolumn{9}{|l|}{ ANOVA } \\
\hline & $d f$ & SS & MS & $F$ & $\begin{array}{c}\text { Significanc } \\
e F\end{array}$ & & & \\
\hline Regression & 1 & 0.03423 & 0.03423 & $\begin{array}{c}11.3647 \\
6\end{array}$ & 0.01337 & & & \\
\hline Residual & 58 & 0.174693 & $\begin{array}{c}0.00301 \\
2 \\
\end{array}$ & & & & & \\
\hline \multirow[t]{2}{*}{ Total } & 59 & 0.208923 & & & & & & \\
\hline & Coefficients & $\begin{array}{c}\text { Standard } \\
\text { Error }\end{array}$ & t Stat & $P$-value & Lower 95\% & $\begin{array}{c}\text { Upper } \\
95 \% \\
\end{array}$ & $\begin{array}{l}\text { Lower } \\
95.0 \% \\
\end{array}$ & $\begin{array}{l}\text { Upper } \\
95.0 \%\end{array}$ \\
\hline Intercept & -0.069587066 & 0.009841 & -7.07132 & 2.22E-09 & -0.08929 & $\begin{array}{c}- \\
0.04989\end{array}$ & $\begin{array}{c}- \\
0.08929\end{array}$ & $\begin{array}{c}- \\
0.04989\end{array}$ \\
\hline X Variable 1 & -0.462097307 & 0.137073 & -3.37117 & $\begin{array}{c}0.00133 \\
7\end{array}$ & -0.73648 & $\begin{array}{c}- \\
0.18772 \\
\end{array}$ & $\begin{array}{c}- \\
0.73648 \\
\end{array}$ & $\begin{array}{c}- \\
0.18772 \\
\end{array}$ \\
\hline
\end{tabular}

